\title{
Hukum Waris Adat dan Hukum Waris Islam dalam Perspektif Perbandingan
}

\author{
Umransyah Alie
}

\begin{abstract}
Customary legacy law consists of the rule about process to give and to move the heritage from one generation to joint heirs. Customary lefacy law originates from tradition or habit that come from human thingking. Islamic legacy law originates from divine revelation of God that is The Holy Al Qur'an. In Indonesia, Islamic legacy law is some customary legacy law that accommodate as Islamic Legacy law written in Compilation of Islamic Law.
\end{abstract}

\section{Pendahuluan}

Salah satu peristiwa hukum yang pasti terjadi pada diri manusia adalah "kematian". Akibat hukum dari peristiwa tersebut menyangkut dengan harta yang ditinggalkannya. Permasalahan yang muncul, bagaimana harta peninggalan diperlakukan, kepada siapa harta itu beralih dan bagaimana caranya.

Di dalam kehidupan manusia, baik pada masyarakat sederhana maupun masyarakat yang sedang berkembang atau yang sudah modem, berbeda-beda di dalam memecahkan persoalan seperti tersebut di atas, yakni tentang harta peninggalan. Di antaranya dengan memperlakukan adat kebiasaan (hukum adat) dan pada kelompok lainnya memakai sistem hukum agama atau kepercayaan yang dianut, seperti hukum waris Islam. Di samping itu terdapat pula hukum yang dibuat dan disusun sedemikian rupa oleh pembentuk undangundang, misalnya Kitab Undang-Undang
Hukum Perdata (BW).

Di Indonesia ketiga macam sistem hkum tersebut hidup di dalam masyarakat sesuai dengan kepercayaan dan agama yang dianut masing-masing. Sejak dahulu sampai sekarang tidak terdapat suatu kesatuan (unifikasi) hukum tentang kewarisan yang dapat diterapkan bagi seluruh, warga negara Indonesia.

Pada paparan di dalam tulisan ini akan dicoba memperbandingkan di antara dua macam sistem hukum kewarisan yang berlaku di Indonesia, yaitu antara "hukum waris adat" dengan "hukum waris Islam".

Tema tersebut dipilih dengan latar belakang pemikiran untuk memperbandingkan kedua macam sistem tersebut, dimana letak perbedaan dan persamaannya serta untuk melihat apakah terjadi adanya saling mengadopsi. Apakah hukum waris Islam me- 
receptie hukum adat ataukah hukum adat yang me-receptie hukum Islam. Sebab, kehadiran hukum Islam (HWI), di Indonesia masyarakatnya telah berlaku hukum adat (hukum waris adat).

Dengan memperbandingkan tersebut diharapkan dapat dilihat mana hukum waris yang murni dan mana hukum waris adat serta mana hukum waris Islam yang di-receptie oleh hukum waris adat dan sebaliknya.

\section{Pengertian Waris}

Istilah waris berasal dari bahasa Arab sebagai bahasa (Islam) dan kemudian telah menjadi bahasa yang baku dalam bahasa Indonesia. Dengan demikian istilah "waris" diadopsi oleh hukum adat.

Adat mengandung beberapa pengertian, yaitu:

a. Aturan (perbuatan) yang lazim dituruti atau dilakukan sejak dahulu kala;

b. Kebiasaan, cara (kelakuan) yang sudah menjadi kebiasaan;

c. Wujud gagasan kebudayaan yang terdiri dari nilai-nilai budaya, norma, hukum dan aturan-aturan yang satu dengan yang lainnya berkaitan menjadi satu sistem.'

Istilah hukum adat (Adat Recht-Belanda) atau Adat Law (Inggris) pertama kali diciptakan oleh Snouck Hurgronje 1893. ${ }^{2}$

Pada dasamya hukum adat itu bersumber pada:

a. volksrecht atau hukum rakyat;

b. hukum adat bernormakan hukum Islam dan hukum Cannoniek (hukum Gereja);

c. hukum yang bernormakan adat kebiasaan daerah atau pranata dari daerah (Kraton I istana: Yogyakarta, Surakarta, Bali).

Kesimpulannya "hukum adat" adalah pada dasarnya adat kebiasaan yang menimbulkan akibat hukum. ${ }^{3}$ Karena di dalam hukum adat juga mengatur tentang masalah kewarisan, di samping masalah-masalah lainnya, maka di dalam konteks ini secara khusus disebut dengan hukum waris adat.

Hilman Hadikusuma, merumuskan bahwa hukum waris adat adalah hukum adat yang memuat garis-garis ketentuan tentang sistem dan asas-asas hukum waris, tentang harta warisan, pewaris dan waris serta cara bagaimana harta warisan itu dialihkan penguasaan dan pemilikannya dari pewaris kepada waris. ${ }^{4}$

Terr Haar menyatakan pendapatnya, bahwa hukum waris adat adalah aturan-aturan hukum yang mengenai bagaimana cara dari abad ke abad penerusan dan peralihan dari harta kekayaan yang berwujud dan tidak berwujud dari generasi pada generasi. ${ }^{5}$

Menurut R.Soepomo, hukum adat waris memuat peraturan-peraturan yang mengatur proses meneruskan serta mengoperasikan barang-barang harta benda dan barang-

1 Departemen P dan KRI, Kamus BesarIndonesia (Jakarta: Balai Pustaka, 1989), hlm. 5-6

2 Yan Pramadya Puspa, Kamus Hukum Edisi Lengkap, Belanda, Indonesia, Inggris.(Semarang: Aneka IImu, 1977), him. 34

${ }^{3} \mathrm{lbid}$.

${ }^{4} \mathrm{Hi}$. Hilman Hadikusuma, Hukum Waris Adat (Bandung: Aditya Bakti, 1993), hlm. 7

$5 \mathrm{Jbid}$. 
barang yang tidak berwujud benda (immateriele goederen) dari suatu angkatan manusia (generatie) kepada keturunannya. ${ }^{6}$

Parä Fuqaha Islam merumuskan tentang hukum waris dilihat dari bahasa (etimologi) dan istilah (terminologi). Dari sudut bahasa "waris" berarti yang berhak menerima pusaka I harta dari pewaris. Harta peninggalan orang yang meninggal (pewaris) disebut mauruts. Hukum waris dalam istilah lain, disebut juga hukum faraidl. Kata faraidl jamak dari faraidlah, diambil dari kata fardlu; dalam istilah Ulama Fiqih Mawaris diartikan bagian yang telah ditetapkan oleh syara.?

Kata fardlu mempunyai arti, yaitu:

a. Taqdir, artinya suatu ketentuan (Q.S. (2): 237)

b. Qath'U, artinya ketetatapan yang pasti (Q.S. (4): 7)

c. Inzal, artinya menurunkan (Q.S. (28): 85)

d. Tábyin, artinya penjelasan (Q.S. (66): 2)

e. Ihlal, artinya menghalalkan (Q.S. (33): 38)

f. 'Atha, artinya pemberian. ${ }^{8}$

Semua pengertian di atas dapat digunakan, sebab dalam Ilmu Faraidl itu mengandung saham-saham (bagian-bagian) yang telah ditentukan dengan pasti besar kecilnya yang fungsinya sebagai suatu pemberian yang bebas dari suatu paksaan dan telah dijelaskan Allah SWT tentang halalnya sesuai dengan peraturan-peraturan yang telah diturunkan al Quran. Dari pengertian secara kebahasan di atas dapat dirumuskan bahwa hukum waris adalah hukum yang mengaindung aturan-aturan tentang pembagian harta peninggalan pewaris setelah meninggal dunia. Aturan-aturan tersebut tercantum dengan jelas di dalam al Quran dan tersebut di dalam as Sunnah.

Dilihat dari sudut pengertian (rumusan) tersebut, yakni sama-sama mengatur tentang tata cara pemindahan hak milik harta kekayaan dari pewaris kepada ahli waris. Sedangkan perbedaannya adalah bahwa pada sistem hukum waris adat pemindahan itu dapat dilakukan sebelum pewaris meninggal dunia, ${ }^{9}$ dan pada sistem hukum waris Islam pemindahan dan pembagian harta yang ditinggalkan pewaris dilakukan setelah meninggal dunia. Dalam pandangan hukum waris Islam, penyerahan harta yang dilakukan pada waktu pewaris masih hidup, dinamakan hibah (pemberian), bukan warisan. Bentuk seperti ini antara lain berlaku di dalam hukum adat Jawa. Perbuatan penerusan atau pengalihan harta dari pewaris kepada waris sebelum pewaris wafat (Jawa, lintiran) dapat tejjadi dengan cara penunjukan, penyerahan kekuasaan atau penyerahan pemilikan atas bendanya oleh pewaris kepada waris. ${ }^{10}$

Kapan lahimya hukum waris adat indonesia tidak ditemukan fakta sejarah yang menunjukkannya. Masyarakat suku bangsa Indonesia yang mendiami kepulauan besar maupun kecil, masing-masing mempunyai tradisi dan budaya di dalam bertingkah laku keseharian. Tradisi dan budaya tersebut bertubungan dengan masalah kepercayaan,

\footnotetext{
${ }^{B}$ Soepomo, Bab-bab Tentang Hukum Adat (Jakarta: Pradnya Paramita, 1983).

${ }^{7}$ Teungku Muhammad Hasbi ash Shiddieqy, Fiqih Mawaris (Jakarta: Pustaka Rizki Putra), hlm. 5

${ }^{8}$ Fatchur Rahman, IImu Waris (Bandung: Al Ma'arif, 1981).

${ }^{\ominus}$ Hi.Hilman Hadikusuma. Hukum Waris Adat, op.cit., him. 8

${ }^{10}$ Ibid. him. 9
} 
perkawinan, kehidupan keiuarga, pemilikan, kematian dan ritus-ritusnya serta bidangbidang lainnya. Hukum lahir sebagai sikap tindak atau perikelakuan yang ajeg, yaitu perikelakuan yang diulang-ulang dengan cara yang sama, yang bertujuan untuk mencapai kedamaian. ${ }^{11}$

Karena sifat dan coraknya yang demikian, maka bentuknya tidak ada yang tertulis, namun ia tumbuh dan berkembang dalam masyarakat kelompok (gerombolan) tersebut dinamakan masyarakat hukum (rechtsgemeenchappen). ${ }^{12}$ Dalam kontek ini termasuk hukum waris adat atau hukum adat waris. ${ }^{13}$

Sejarah terbentuknya hukum waris Islam berbeda dengan sejarah tumbuh dan berkembangnya hukum waris adat, baik hukum waris adat bangsa Arab sebelum Islam, maupun hukum waris adat di Indonesia.

Sebelum Islam diturunkan Allah melalui Nabi dan Rasul-Nya yang terakhir, yakni Nabi Muhammad SAW, hukum waris adat bangsa Arab (Jahiliyah) berdasarkan pada kebiasaankebiasaan yang dilakukan secara turuntemurun dari suatu generasi kepada generasi berikutnya. Dan setelah Islam datang, hukum waris adat dihapuskan, diganti dengan syariat (hukum) Islam, yang bersumber kepada wahyu-wahyu Allah (Quran) dan Sunnah/ Hadits-hadits Nabi saw.

Tonggak yang sangat penting di dalam pertumbuhan dan perkembangan hukum kewarisan Islam adalah pada tahun ke-3 $\mathrm{H}$ $(625 \mathrm{H})$ terjadi perang antara umat Islam dengan kaum kafir atau musyrik di suatu tempat yang bernama "bukit/gunung Uhud". Setelah itu terjadilah kasus kewarisan yang terkenal dengan kasus Sa'ad bin Rabi'. la meninggalkan seorang isteri dan dua orang anak perempuan dan satu orang saudara lakilaki sekandung. Menurut hukum waris adat bangsa Arab pada saat itu (sebelum Islam), semua harta peninggalan Sa'ad diambil (diwaris) oleh saudara laki-lakinya, sebagai satu-satunya ahli waris yang berhak memperoleh harta peninggalan Sa'ad bin Rabi'. Karena, perempuan dan anak-anak di bawah umur baik laki-laki ataupun perempuan tidak boleh mewaris. Atas tindakan ipamya tersebut, isteri Sa'ad bin Rabi' menghadap dan mengajukan gugatannya kepada Rasulullah saw. Oleh sebab peristiwa tersebut turunlah wahyu Allah SWT (ayat-ayat Quran) yang menerangkan cara pemecahan terhadap kasus tersebut. Kasus Sa'ad bin Rabi' ini merupakan sebagai sebab turunnya (asbabun nuzul) ayat:ayat kewarisan yang tercantum pada surah an-Nisa (4) ayat (11) dan (12)..$^{14}$

Dengan demikian jelaslah bahwa historis dan latar belakang hukum kewarisan Islam pertama didasarkan adanya kasus atau peristiwa yang terjadi. Dan ini merupakan salah satu hikmah mengapa ayat-ayat Quran itu diturunkan secara berangsur-angsur (tidak

"Soerjono Soekanto, Bahan PIH, Mengenal Sosiologi Hukum (Bandung: Alumni, 1986).

12 B. Ter Haar Bzn, Beginselen En Stelsel Van Het Adatrech, Terjemah K.Ng.Soebakti Poesponoto (Jakarta: PT Pradnya Paramita, 1987), hlm. 6

${ }^{13}$ Soepomo, op.cit. hlm. 81

"Qomaruddin Shaleh, A.A.Dahlan, M.D.Dahlan, Asbabun Nuzul, Latar Belakang Hsitoris Tununnya Ayat-ayat Al Quran (Bandung: Diponegoro, . 1975), hlm. 119-120 
sekaligus).${ }^{15} \mathrm{Di}$ samping itu dengan turunnya ayat-ayat kewarisan tersebut sebagai hukum yang menegaskan tidak berlakunya lagi hukum adat waris, baik bagi bangsa Arab, maupun bangsa-bangsa di dunia ini yang telah menyatakan diri sebagai muslim. Karena berdasarkan firman Allah dalam surah al Ahzab (33): 36 menerangkan sebagai berikut:

Artinya: "Dan tidaklah patut (wajar) bagi laki-laki yang mukmin dan tidak (pula) bagi perempuan yang mukmin, apabila Allah dan Rasul-Nya telah menetapkan suatu ketetapan (hukum), akan ada bagi mereka pilihan (yang lain) tentang urusan mereka. Dan barang siapa yang mendurhakai (maksiat) Allah dan Rasul-Nya maka sungguhlah dia telah sesat, sesat yang nyata". 16

Dengan uraian singkat di atas terlihat, bahwa hukum waris adat bersumber pada tradisi I kebiasaan-kebiasaan perilaku yang lahir dari akal pikiran manusia, sedangkan hukum waris Islam bersumber pada wahyu (al Quran).

\section{Ahli Waris}

Bangsa Arab sebelum Islam susunan kekeluargaannya berpatrialchat, sehingga garis keturunannya ditarik dari pihak bapak (laki-laki). Karena itu sistem hukum kewarisan mereka pada saat itu hanya pihak laki-laki yang berhak waris. Bentuk dan corak seperti itu juga terdapat suku bangsa lain seperti Indonesia, meskipun tidak persis sama.
Di Indonesia ada tiga macam dasar pertalian keturunan, yaitu:

a. pertalian darah menurut garis bapak (patrilineal), misalnya pada orang-orang Batak, Nias, Sumba;

b. pertalian darah menurut garis ibu (matrilineal), misalnya pada orang/ Suku Minangkabau;

c. pertalian darah menurut garis keturunan ibu dan bapak, seperti orang-orang Jawa, Sunda, Aceh, Bali dan Kalimantan. ${ }^{17}$

Sistem-sistem tersebut amat berpengaruh di dalam garis hukum kewarisan tentang siapa yang menjadi ahli waris. Seperti orang Batak, anak laki-laki terutama yang telah dewasa sebagai ahli waris, sedangkan anak perempuan tidak sebagai ahli waris. Sebaliknya di Minangkabau, sebagai ahli waris adalah anak perempuan. Sedangkan seperti Kalimatan, Jawa, Sunda, Aceh, Bali yang menganut sistem bilateral, anak laki-laki dan anak perempuan mempunyai kedudukan yang sama sebagai ahli waris.

Bagaimana kedudukannya "anak angkat" (adopsi) dan anak tiri di dalam kewarisan adat? Pada dasamya (umumnya) anak angkat tidak berhak waris. Tetapi pada beberapa daerah, seperti Lampung, Jawa, masyarakat adat Dayak Kendayan, Dayak Benawas di Kalimantan Barat, anak angkat kedudukannya sebagai ahli-waris, tidak berbeda dari anak kandung bapak angkatnya. ${ }^{18}$

${ }^{15}$ Lihat al Quran dan Terjemahnya (Jakarta: Yayasan Penyelenggara Penterjemah/Penafsir Al Quran, 1971), hilm. 16.

\footnotetext{
${ }^{t 6} \mathrm{lbid} ., \mathrm{hlm} .673$

${ }^{17}$ Soepomo, op.cit, hlm. 51

${ }^{18}$ Hi.Hilman Hadikusuma, op.cit, hlm. 80
} 
Anak tiri adalah anak yang dibawa dalam suatu perkawinan baik oleh suami atau dari pihak isteri. Kedudukan anak tiri dalam kewarisannya berbeda dengan anak kandung. Anak tiri hanya berhak waris kepada bapak atau ibu kandungnya, tidak kepada bapak/ibu tirinya. Namun, untuk daerah Lampung anak tiri ada kemungkinan sebagai ahli waris, bila terjadi perkawinan levirat. ${ }^{19}$

Di dalam Islam sebab-sebab terjadinya waris mewaris adalah karena adanya hubungan nasab atau kerabat, hubungan perkawinan dan hubungan wala', yaitu hubungan antara bekas budak yang dimerdekakan dengan orang yang memerdekakannya, apabila budak itu tidak mempunyai ahli waris. ${ }^{20}$

Ahmad Azhar Basyir, MA menambahkan selain dari sebab-sebab tersebut, yaitu tujuan Islam (jihatul Islam), yaitu baitul maal yang menampung harta warisan orang yang tidak meninggalkan ahli waris. ${ }^{21}$

Sebab-sebab tersebut di atas belum . dapat dilaksanakan, bila syarat-syaratnya belum terpenuhi, yaitu:

a. Pewaris benar-benar meninggal dunia, baik secara hakiki maupun secara hukum (berdasarkan keputusan hakim).

b. Ahli waris benar-benar masih hidup pada waktu pewaris meninggal dunia.

c. Dapat diketahui secara benar (shahih) sebab warisan pada ahli waris.

Ahli waris dalam hukum Islam dilihat dari sudut jenisnya laki-laki dan perempuan, sedangkan dilihat dari segi haknya atas harta warisan terdiri dari: ahli waris dzawil furudl, 'Ashabah dan waris dzawil arham.

Ahli waris laki-laki sebanyak 15 dan ahli waris perempuan berjumlah 10 . Bila terkumpul seluruhnya (ahli waris masih hidup), maka yang berhak waris adalah: ayah, ibu, suami/isteri, dan anak.

Ahli waris dzawil furudl ialah ahli waris yang telah ditetapkan bagian-bagiannya baik di dalam al Quran maupun pada hadits-hadits Nabi saw, yaitu: $1 / 2,1 / 3,1 / 4,1 / 6,1 / 8$ dan $2 / 3$. Mereka itu adalah, suami, isteri, ayah, ibu, anak perempuan, cucu perempuan (dari anak lakilaki), saudara perempuan sekandung, saudara perempuan seayah, saudara laki-laki dan perempuan se ibu, kakek dan nenek.

Ahli waris Ashabah adalah ahli waris yang tidak ditentukan bagiannya, akan tetapi mereka dapat menerima seluruh harta warisan, jika tidak ada ahli waris dzawil furudl, dan jika dzawil furudl ada, waris ashabah berhak atas sisanya, bila tidak ada sisanya tidak menerima/mendapat bagian apapun. ${ }^{22}$ Ahli waris ashabah ini ada tiga macam, yaitu, waris ashabah nafsihi, ashabah bil ghairi dan ashabah ma'al ghain.

Ahli waris golongan ketiga adalah ahli waris dzawil arham yaitu ahli waris yang mempunyai hubungan famili dengan si pewaris (si mayit), yaitu: cucu laki-laki atau perempuan, anak-anak dari perempuan, kemenakan laki-laki atau perempuan.

${ }^{19} \mathrm{lbid}$. hlm. $77-78$.

${ }^{20}$ Fatchur Rahman, op. cit., hlm. hlm. 14

${ }^{21}$ Ahmad Azhar Basyir, Hukum Waris Islam (Yogyakarta: Bagian Penerbitan Fakultas Hukum UII, 1979), 22 Ibid., him. 24 
:Dari uraian di atas terlihat àdanya perbedaan dan persamaan antara hukum waris adat dengan hukum waris Islam. Perbedaannya di dalam menetapkan ahli waris pada masyarakat adat yang tidak seragam antara masyarakat adat yang satu dengan lainnya. Sedangkan di dalám hukum waris Islam, ketentuan dan ketetapan ahli waris yang telah digariskan di dalam al Quran dan Sunnah berlaku bagi masyarakat Islam di tempat manapun. Anak angkat di dalam hukum waris adat Islam tidak berhak waris. Di samping itu menuruthukum waris adat (seperti Jawa), harta pewaris dapat dibagikan/diberikan kepada.ahli waris : pada waktu pewaris masih hidup. Sedangkan di dalam hukum waris Islam, waris mewaris baru terjadi setelah pewaris meninggal dunia (mati). Di dalam hukum waris adat tidak dikenal âdanya penggolongan ahli waris, berbeda dengan hukum waris Islam, dan bahkan ada sebagian dari masyarakat adat yang menetapkan hanya laki-laki (yang tertua) yang berhak waris (menguasai) harta warisan, seperti Minangkabau. Hukum waris Islam tidak membedakan hak antara ahli waris laki-laki dan perempuan, sésuai dengan prinsip hukum waris Islam.

Prinsip-prinsip hukum waris Islam antara lain:

a. Warisan adalah ketetapan hukum, terutama hukum yang telah ditetapkari Allah dan Rasul-Nya.

b. Warisan terbatas dalam lingkungan keluarga, dengan adanya hubungan perkawinan atau karena hubungan nasab (keturunan) yang sah. c. Keluarga yang dekat hubungannya dengan si mayit (pewaris) lebih diutamakan dari pada yang jauh; dan yaing lebih kuat hubungannya dengan si mayit (pewaris) lebih diutamakan dari pada yang lemah.

d. Hukum waris Islam tidak membedakan hak anak-anak baik yang telah dewasal belum, laki-laki maupun perempuan.

e. Hukum waris Islam membedakan besarkecilnya bagian-bagian tertentu ahli waris, diselaraskan dengan kebutuhannya dan kewajibannya, di samping memandang jauh dekatnya hubungan dengan si mayit (pewaris). ${ }^{23}$

Perbedaan lain yang juga. sangat menarik untuk dicermati adalah kedudukan janda atau duda (balu, istilah hukum adat) bukan sebagai waris, seperti pada orang Batak (sistem patrilineal) dan juga masyarakat adat Lampung. Demikian pula di dalam sistem matrilineal, seperti di Minangkabau, seorang duda tidak sebagai waris dari isterinya yang mati (meninggal dunia). ${ }^{24}$ Di dalam hukum waris Islam, janda atau duda berkedudukan sebagai ahli waris bila salah satu di antaranya meninggal dunia (mati).

Persamaan antar kedua macam sistem kewarisan adalah, bahwa.ahli waris didasarkan pada garis nasab atau keturunan dan pada sebagian masyarakat adat yang juga mendasarkan pada perkawinan.
${ }^{23} \mathrm{Ibid.,} \mathrm{him.} 10$

${ }^{24}$ Hi. Hilman Hadikusuma, op.cit, hlm. 86-88. 


\section{Harta Peninggalan}

Secara umum "warisan" adalah semua harta benda yang ditinggalkan seorang yang meninggal dunia (pewaris). ${ }^{25}$ Menurut Hi.Hilman Hadikusuma, harta benda itu baik sudah dibagi atau belum terbagi atau memang tidak dibagi. ${ }^{26}$

Di dalam hukum adat dikenal beberapa istilah harta kekayaan seseorang, seperti harta asal, harta pencaharian/perkawinan, harta pusaka, harta peninggalan tidak terbagi dan harta peninggalan terbagi. Di samping itu dikenal pula apa yang banyak disebut harta pusaka tinggi dan harta pusaka rendah.

Pada pengertian lain disebutkan, bahwa harta peninggalan adalah harta waris yang akan dibagikan kepada ahli waris, atau dengan kata lain, harta secara keseluruhannya yang terlihat ada hubungan pemilikannya dengan si mati, kemudian dikurangi dengan hutang keluarga, dipisah dan ditentukan harta suami (yang meninggal) dari harta isteri dan terakhir harta suami ini dikurangi hutang dan wasiat. ${ }^{27}$

Dari beberapa rumusan di atas terlihat para pakar hukum berbeda-beda di dalam memberikan pengertian tentang "harta peninggalan" menurut hukum adat. Demikian pula bila dibandingkan dengan rumusan/ pengertian yang diberikan oleh para fuqaha. Di antaranya adalah sebagai berikut:
Sayyid Sabiq mengutip perkataan lbnu Hazm, bahwa sesungguhnya Allah telah mewajibkan waris pada harta; bukan yang lain, yang ditinggalkan manusia sesudah dia mati. ${ }^{28}$

Di dalam kitab "Hukum Waris Menurut Quran dan Hadits" harta waris adalah sesuatu yang ditinggalkan oleh pewaris, baik harta bergerak maupun tidak bergerak. ${ }^{29}$

Bila diruju' kepada ayat-ayat al Quran tentang masalah waris di sana disebutkan maataraka/mimma taraka yang artinya "harta yang ditinggalkan". Bunyi ayat seperti itu sering kali disebutkan secara berulang-ulang: Berdasarkan ayat tersebut, harta warisan adalah harta yang ditinggalkan, maksudnya harta yang ditinggalkan seseorang karena kematian.

Dari rumusan-rumusan tersebut di atas terlihat adanya persamaan antara "hukum waris adat" yang ditinggalkan seseorang yang meninggal dunia. Perbedaannya terlihat pada perumusan harta yang ditinggalkan. Al Quran maupun hadits menyebutkan secara umum, karenanya menimbulkan interpretasi yang bermacam-macam, dan sangat kondisional.

Di dalam kompilasi Hukum Islam pada Pasal 171 huruf (d) dan (e) dibedakan antara "harta peninggalan" dengan "harta warisan". Menurut KHI, harta peninggalan adalah harta yang ditinggalkan oleh pewaris, baik berupa

${ }^{25}$ Ensiklopedia Indonesia N-Z W.van Hoeve Bandung's Gravenhage., hlm. 1419, dalam Hi.Hilman Hadikusuma, op.cit., hIm. 35

${ }^{26} \mathrm{Ibid}$.

${ }^{27}$ Sayuti Thalib, Hukum Kewarisan Islam di Indonesia (Jakarta: PT. Bina Aksara, 1982), h/m.85.

${ }^{28}$ Ibnu Hazm, dalam Sayyid Sabiq, Fiqih Sunnah, Jilid 14; dindonesiakan oleh Drs. Mudzakir,AS (Bandung: PT. AlMa'arif, 1987), him. 238

${ }^{29}$ Muhammad Ali Ash Shabuni, Hukum Waris Menurut Al Quran dan Hadits, Alih Bahasa Drs.Zaini Dahlan (Bandung: Trigenda karya Bandung), hlm. 162 
harta benda yang menjadi miliknya maupun hak-haknya. Dan harta warisan dirumuskan adalah harta bawaan ditambah bagian dari harta bersama setelah digunakan untuk keperluan pewaris selama sakit sampai meninggalnya, biaya pengurusan jenazah (tajhio), pembayaran utang dan pemberian untuk kerabat.

\section{Tata Cara Pembagian}

Di dalam hukum waris adat tidak mengenal cara pembagian dengan perhitungan matematia. ${ }^{30}$ Karena (sebagaimana telah diuraikan pada paparan terdahulu) sistem pewarisan yang berbeda-beda maka cara pembagiannya pun berbeda-beda pula. Di sini dapat dikemukakan satu contoh, seperti adat Jawa di mana cara pembagian dilakukan ada dua cara, yaitu:

a. dengan cara segendung sepikul, artinya bagian anak lelaki dua kali lipat bagian anak perempuan, atau

b. dengan cara dum-dum ketupat, artinya bagian anak lelaki dua imbang sama dengan bagian anak perempuan. ${ }^{31}$

Bagimana cara perhitungannya di dalam hukum waris adat tidak dikenal adanya suatu ilmu tersendiri (khusus) tentang cara pembagian harta peninggalan (waris).

Di dalam hukum waris Islam, cara pembagian harta warisan disebut dengan istilah ilmu faraidl, yaitu ilmu tentang cara pembagian harta warisan, suatu cara yang cukup unik. Karena itu dalam. sebuah hadits Nabi saw menyatakan yang artinya sebagai berikut:

"Pelajarilah faraidl dan ajarkanlah kepada orang banyak, karena faraidl adalah separo ilmu dan mudah dilupakan orang serta ilmu yang pertama kali hilang". (HR. Ibnu Majah dan Ad Daruquthni)

Pada contoh di atas (adat Jawa) cara pembagian seperti poin (a) mempunyai kesamaan dengan waris Islam, tetapi untuk poin (b) tidak sesuai dengan ajaran (hükum) Islam. Demikian pula cara pembagian yang dilakukan semasa pewaris masih hidup kepada ahli waris dengan menyerahkan kepada anak lelaki yang tertua atau anak perempuan atau mungkin kepada anak yang bungsu (terakhir) tidak diajarkan di dalam islam (hukum waris Islam).

Dalam perkembangan hukum 'kewarisan Islam di indonesia terdapat beberapa hukum kewarisan adat yang telah dituangkan menjadi hukum kewarisan islam yang termuat di dalam kompilasi Hukum Islam. Misalnya tentang harta bersama (gono-gini), anak angkat, harta kekayaan berupa tanah (lahan) pertanian yang tidak boleh dibagi-bagi, karena kurang dari 2 ha, pembagian secara musyawarah (damai/ ishlah). ${ }^{32}$

\footnotetext{
${ }^{30}$ Hi.Hilman Hadikusuma, op.cit., hlm. 105

${ }^{31} \mathrm{lbid}$, hlm. 106

${ }^{32}$ Lihat lebih lanjut KHI, PSI. 183, 190 dan 209
} 


\section{Simpulan}

Setelah diperbandingkan antara hukum waris adat dengan hukum waris Islam, terlihat adanya perbedaan di samping persamaan antara keduanya. Dan pada sisi lain sebagian ada yang di-receptie oleh hukum waris Islam, demikian pula sebaliknya, seperti pada masyarakat adat Minangkabau yang terungkap dalam adagium: 'Adat bersendi syara', syara' bersendi Kitabullah".

\section{Daftar Pustaka}

Basyir, Ahmad Azhar, Hukum Waris Islam, Yogyakarta: UII Pers, Edisi III, 1979.

Departemen Pendidikan dan Kebudayaan RI, Kamus Besar Bahasa Indonesia, Jakarta: Balai Pustaka, Cet. II. 1989.

Rahman, Fatchur, IImu Waris, Bandung: A! Ma'arif, 1981.

Hadikusuma, Hi.Hilman, Hukum Waris Adat, Bandung: Aditya Bakti, 1993.

Ash Shabuni, Muhammad Ali, Hukum Waris Menurut Al Quran dan Hadits, Terjamah Zaini Dahlan, Bandung: Trigenda Karya, Cet. I, 1995.
Saleh, Qamaruddin, AA Dahlan, M.D. Dahlan, Asbabun Nuzul, Latar Belakang Historis Turunnya Ayat-Ayat Quran, Bandung: CV Diponegoro Cet.ll, 1975.

R.Soepomo, Bab-Bab Tentang Hukum Adat. Jakarta: Pradnya Parmita Cer.ke-8, 1983.

Thalib, Sayuti, Hukum Kewarisan Islam di Indonesia, Jakarta: PT Bina Aksara Cet. I, 1982.

Sabiq, Sayyid, Fiqih Sunnah, Tarjamah Mudzakir AS, Bandung: PT Al Ma'arif, 1987.

Bzn, Terr Haar. Beginselen En Stelsel van Het Adatrecht, Terjamah K.Ng. Soebakti Poesponoto, Asas-Asas dan Susunan Hukum Adat, Jakarta: PT Pradnya Paramita Cet.ke-9, 1987.

Ash Shiddiegy, Teungku Muhammad Hasbi, Fiqih Mawaris, Semarang: PT Pustaka Rizqi Putra, 1997.

Puspa, Yan Pramadya, Kamus Hukum Edisi Lengkap, Belanda, Indonesia, Inggris. Semarang: Aneka IImu, 1974. 